\begin{tabular}{|c|cc|c|c|}
\hline FORT -SAID ENGINEERING RESEARCH JOURNAL & Faculty of Engineering & -port said university \\
Volume 19 & No. $1 \quad$ March2015 pp:121:128
\end{tabular}

\title{
Effect of DC Link Capacitance on Stand-Alone PV System Operation with Fluctuated DC Resistive Loads
}

Ali H. Kasem Alaboudy ${ }^{1}$, Adel A. Elbaset ${ }^{2}$ and Saad A. Mohamed Abdelwahab ${ }^{1}$

\begin{abstract}
This paper presents a MATLAB/SIMULINK-based modeling and simulation scheme suitable for studying the $I-V$ and $P-V$ characteristics of a PV array under constant and variable solar irradiations and ambient temperatures. The PV array is connected with fluctuated dc resistive load. This work focuses on addressing the effect of the dc link capacitance on stand-alone photovoltaic system operation with fluctuated dc resistive load. Different loads variations with $\pm 10 \%$ and $\pm 20 \%$ have been conducted under constant of solar irradiation and ambient temperature. Further, variable solar irradiations and ambient temperatures have been conducted. The selection of the dc link capacitance value for certain fluctuated dc resistive load is discussed. This work focuses also on addressing the effect of dc link capacitance on standalone PV system operation with a fixed dc resistive load subjected to variable solar radiations and ambient temperatures. The presented work is very useful for PV engineers and experts who require simple, fast and accurate PV calculations to design their systems.
\end{abstract}

\section{Keywords: PV array, dc link capacitance, fluctuated dc resistive load.}

\section{INTRODUCTION}

The growing demand for electric energy throughout the world has highly motivated the use of renewable sources of energy. Among the unconventional renewable based energy sources that have been intensively studied, photovoltaic (PV) energy is now becoming a real promising and economical source of energy [1-2]. PV is a technology that turns the sun radiation energy directly to electricity. The PV energy has many advantages. It is a clean energy source that has virtually no environmental polluting impact, highly reliable, flexible in terms of size, and needs minimal maintenance [3, 4].

Typically, the performance of the PV system depends on the variation of solar irradiation and ambient temperature. For stand-alone PV systems, in addition to incident radiation and temperature, the type and behavior of electric loads play a great role in system performance enhancement. In order to maximize the PV power capturing, maximum power point tracking (MPPT) strategies are driven to tune the loading conditions to meet the contemporary PV power generation. This definitely maximizes the PV power/energy utilization under varying ambient temperature and solar irradiation conditions.

${ }^{1}$ Electrical Department, Faculty of Industrial Education, Suez University, Suez, Egypt, E-mail: ali_hkasem@yahoo.com , saad.abdelwahab@suezuniv.edu.eg

${ }^{2}$ Faculty of Engineering, Minia University, Egypt, and Faculty of Postgraduate Studies for Advanced Science, Beni-Suef University, Egypt, E-mail: AdeL.Soliman@mu.edu.eg
The price of the PV modules were in the past the major contribution to the cost of these systems. A downward tendency is now seen in the price for the PV modules due to a massive increase in the production capacity of PV modules. For example, the price per watt for a PV module was between 4.4 - 7.9 USD in 1992 [2] and now the price significantly dropped. PV studies rely on a PV simulation model to develop MPPT algorithms and control strategies [5]. PV system designers need a reliable and easy-to-implement model to predict PV energy production under various operating conditions [5].

The performance of a stand-alone PV system depends on electric load as well as ambient temperature $\left(\mathrm{T}_{\mathrm{x}}\right)$ and solar irradiation $\left(\mathrm{S}_{\mathrm{x}}\right)$. The $\mathrm{dc}$ link capacitance affects the stand-alone photovoltaic system operation with fluctuated dc resistive under fixed/variable solar radiations and ambient temperatures. PV array to match electric load to deliver maximum available power to achieve the maximum photovoltaic energy utilization at all times under constant and variable ambient temperature and solar irradiation conditions with fluctuated dc resistive load.

The main objective of this paper is how the power matching for stand-alone PV systems with maximum power tracking in the presence of fluctuated dc resistive loads can be maintained. The optimum tuning of the dc link capacitance positively affects the stand-alone PV system operation with fluctuated dc resistive loads.

In this paper, MATLAB/SIMULINK based models of the solar PV cell, module and array are developed 
and presented based on the mathematical equations. The effect of dc link capacitance on stand-alone photovoltaic system operation with fluctuated dc resistive load. Further, the impact of variable solar irradiations and ambient temperatures has been examined. A guideline to select the value of dc link capacitance for certain fluctuated dc resistive load is presented. Different scenarios of fluctuated $\mathrm{dc}$ resistive load on PV characteristic have been conducted.

\section{STAND-ALONE PV SYSTEM DESCRIPTION}

Fig. 1 shows the equivalent circuit of a standalone PV system. The Matlab/Simulation model is described in Fig. 2. As shown in Fig. 1 and Fig. 2, the photovoltaic array (PVA) model is connected to a diode (D1), an RLC filter and dc resistive loads. The following points are considered in the simulation.

- The modules of the PVA are arranged in series and parallel to achieve the required voltage and current ratings.

- The blocking diode is used to block the reverse current flow.

- The input RLC filter allows the use of a valid quasi-static model of the PV array and also acts as an added energy storage device.

The dc resistive loads $(500 \mathrm{~W}, 300 \mathrm{~W}, 100 \mathrm{~W}$ and $200 \mathrm{~W}$ ) are connected in parallel with PV array via controlled switches.

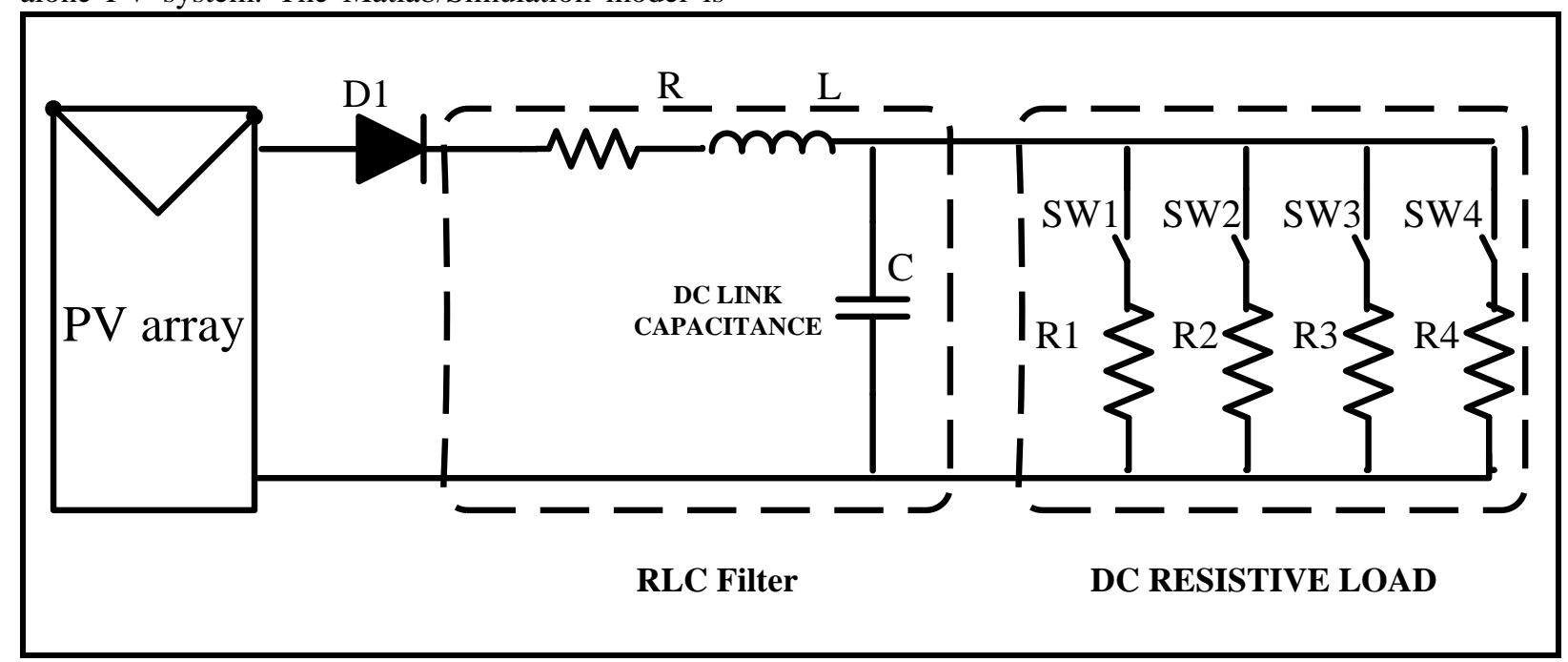

Fig. 1: A PVA model with controlled switched dc resistive loads.

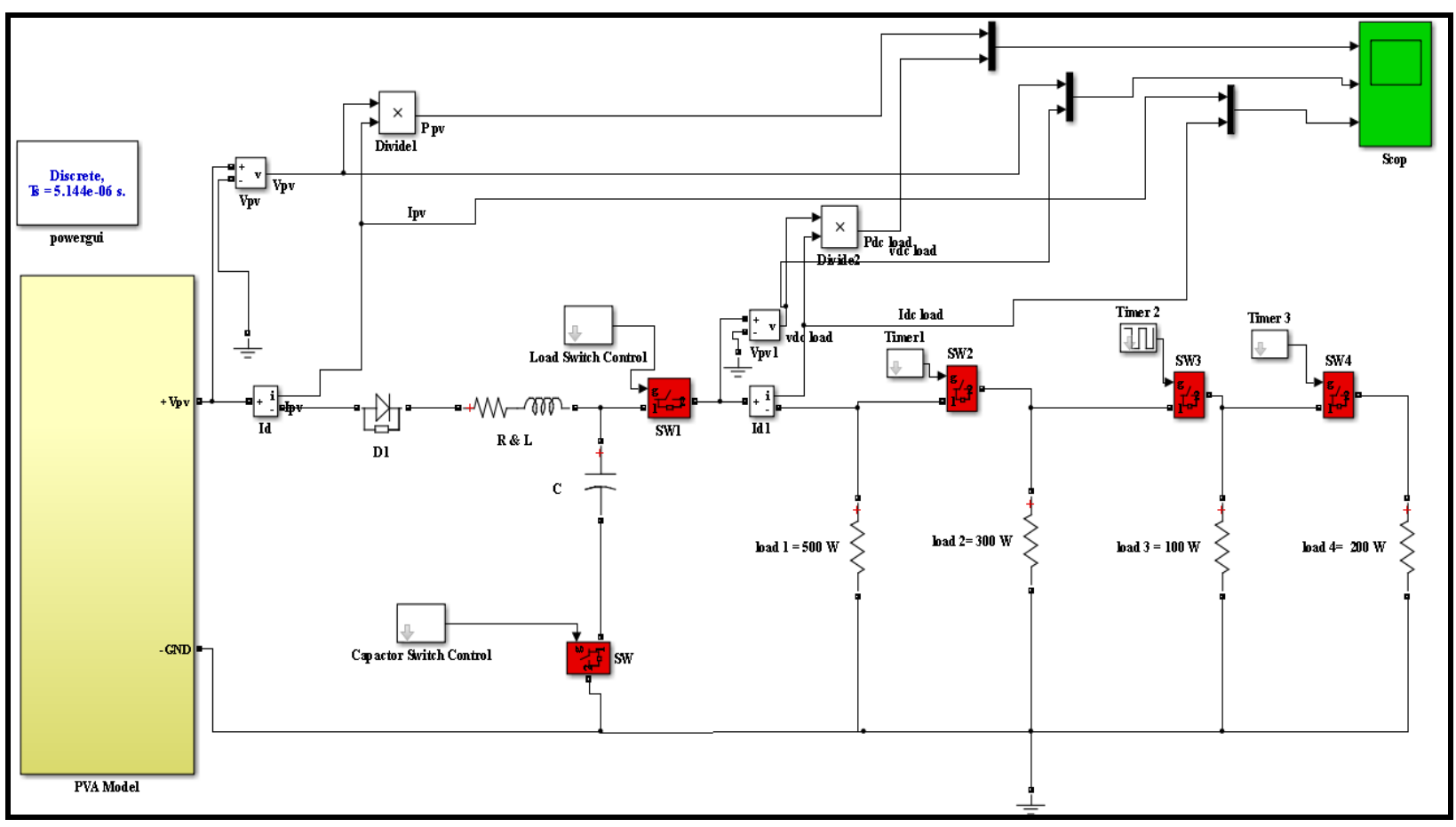

Fig. 2: Simulink block diagram of the PVA model with controlled switched dc resistive loads. 


\section{MATHMATECAL MODELING OF A PV ARRAY}

Solar cells or PV cells consist of a p-n junction fabricated in a thin wafer or layer of semiconductor. In the dark, the I-V output characteristic of a solar cell has an exponential characteristic similar to that of a diode [6].

A model of moderate complexity is used in this research to increase accuracy by adding:

- Temperature dependency of the photo-generated current $\left(\mathrm{I}_{\mathrm{Ph}}\right)$.

- Temperature dependency of the reverse saturation current of the diode $\mathrm{D}_{\mathrm{o}}\left(\mathrm{I}_{\mathrm{o}}\right)$.

- Series resistance $\left(\mathrm{R}_{\mathrm{s}}\right)$ which gives a more accurate shape between the maximum power point and the open circuit voltage.

- A single shunt diode $\mathrm{D}_{\mathrm{o}}$ was used with the diode quality factor set to achieve the best curve matching. The equivalent circuit of the solar cell is shown in Fig. 3.

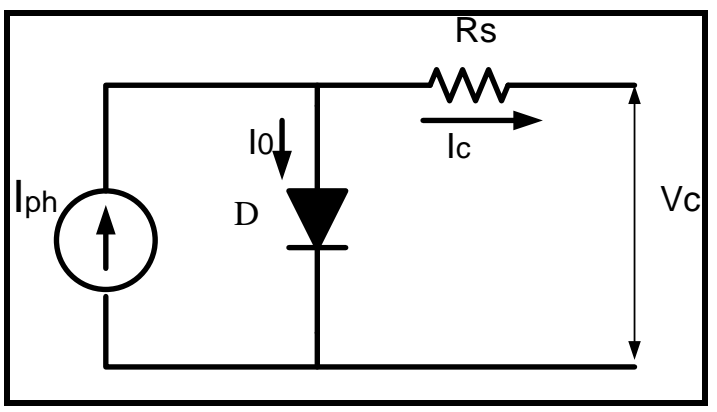

Fig. 3: The equivalent circuit of the solar cell.

The equations that describe the I-V characteristics of the single solar cell are [6-11]:

$$
\begin{aligned}
& I_{C}=I_{p h}-I_{O}\left\{e^{\frac{q\left(V_{g}+I_{g} R_{s}\right)}{A K T_{x}}}-1\right\} \\
& I_{p h}=I_{p h\left(T_{C}\right)} *\left\{1+K_{o}\left(T_{x}-T_{c}\right)\right\} \\
& I_{p h\left(T_{c}\right)}=\frac{S_{x} * I_{S C\left(T_{c} S_{C}\right)}}{S_{c}} \\
& K_{O}=\frac{I_{S C\left(T_{1}\right)}-I_{S C(T c)}}{\left\{T_{1}-T_{C}\right\}} \\
& I_{O}=I_{o(T c)} \cdot\left\{\frac{T_{x}}{T_{c}}\right\}^{3 / A} \cdot e^{\left(\frac{q V_{c}}{A K\left(1 / T_{x}-1 / T_{c}\right)}-\right)}
\end{aligned}
$$

From Eq. 1

$$
V_{c}=\frac{A K T_{c}}{q} \ln \left\{\frac{I_{p h}+I_{o}-I_{c}}{I_{o}}\right\}-R_{S} I_{c}
$$

For PV array with solar cells arranged in series and parallel, the V-I characteristics are:

$$
V_{c}=\frac{N_{s} A K T_{c}}{q} \ln \left\{\frac{N_{p} I_{p h}+N_{p} I_{o}-I_{c}}{N_{p} I_{o}}\right\}-\left\{\frac{N_{s}}{N_{p}} R_{S} I_{c}\right\}
$$

Where,

$\mathrm{V}_{\mathrm{c}}$ : Solar cell terminal voltage $(\mathrm{V})$

$\mathrm{I}_{\mathrm{c}}$ : Solar cell terminal current $(\mathrm{A})$,

$\mathrm{I}_{\mathrm{ph}}$ : Photo-generated current, function of junction temperature and irradiation level (A),

$\mathrm{I}_{\mathrm{o}}$ : Reverse saturation current of the diode $\mathrm{D}_{\mathrm{o}}$ due to diffusion mechanism (A),

$\mathrm{V}_{\mathrm{oc}}$ : Solar cell open circuit voltage $(\mathrm{V})$,

$\mathrm{I}_{\mathrm{sc}}$ : Solar cell short circuit current (A),

$\mathrm{R}_{\mathrm{s}}$ : Series resistance of the solar cell $(0.001 \mathrm{ohm})$,

$\mathrm{N}_{\mathrm{s}}$ : Number of solar cells connected in series,

$\mathrm{N}_{\mathrm{p}}$ : Number of solar cells connected in parallel,

A: Quality factor of diode $\mathrm{D}_{\mathrm{o}}$,

$\mathrm{K}$ : Boltzman's constant $\left(1.38^{*} 10^{-23} \mathrm{~J} /{ }^{\circ} \mathrm{K}\right)$

$\mathrm{q}$ : Charge on an electron $\left(1.60 * 10^{-19} \mathrm{C}\right)$,

$\mathrm{T}_{\mathrm{x}}$ : Solar cell ambient temperature $\left({ }^{\circ} \mathrm{C}\right)$,

$\mathrm{T}_{\mathrm{C}}$ : Solar cell reference operating temperature (20 $\left.{ }^{\circ} \mathrm{C}\right)$,

$\mathrm{S}_{\mathrm{x}}$ : Solar irradiance level $\left(\mathrm{W} / \mathrm{m}^{2}\right)$,

$\mathrm{S}_{\mathrm{c}}$ : Solar Cell rated irradiation $\left(800 \mathrm{~W} / \mathrm{m}^{2}\right)$.

When the cell is not illuminated, the relationship between the cell's terminal voltage $\left(\mathrm{V}_{\mathrm{c}}\right)$ and current $\left(\mathrm{I}_{\mathrm{c}}\right)$ is given by the Shockley diode equation. When the cell is open circuited and illuminated, the photogenerated current $\left(\mathrm{I}_{\mathrm{ph}}\right)$ flows entirely in the diode.

\section{SIMULATION RESULTS A. PV MODEL VALIDATION}

The PVA model (described in Section III) coupled with the dc link and resistive local loads is simulated using Matlab/Simulink, as shown in Fig. 2. To emulate load variations, controlled switched $\mathrm{dc}$ resistive branches are used. The PV array supplies power to mainly four resistive dc loads $(500 \mathrm{~W}$, $300 \mathrm{~W}, 100 \mathrm{~W}$ and $100 \mathrm{~W}$ ) connected in parallel. The branch of the dc link capacitance is controlled with a dedicated switch to highlight the effect of the dc link capacitance in a PV system.

The nonlinear current-voltage (I-V) characteristics of the PV array and Power-Voltage $(\mathrm{P}-\mathrm{V})$ characteristics of PVA at $\mathrm{T}_{\mathrm{x}}=25{ }^{\circ} \mathrm{C}$ and $\mathrm{S}_{\mathrm{x}}=1000 \mathrm{~W} / \mathrm{m}^{2}$ are given in Fig. 4 and Fig. 5 respectively.

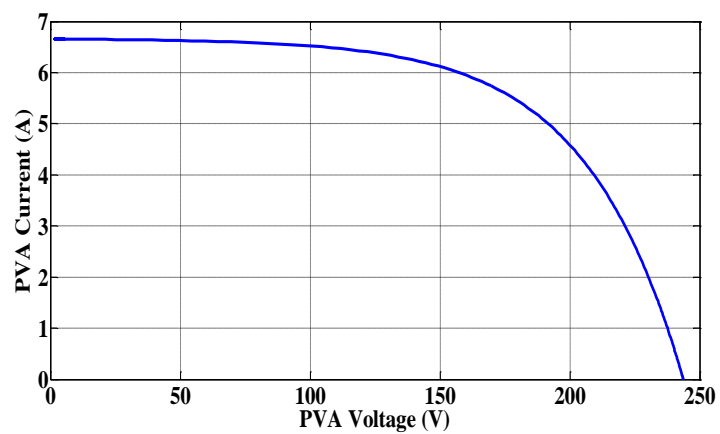

Fig. 4: Current-Voltage (I-V) characteristics of the PVA 


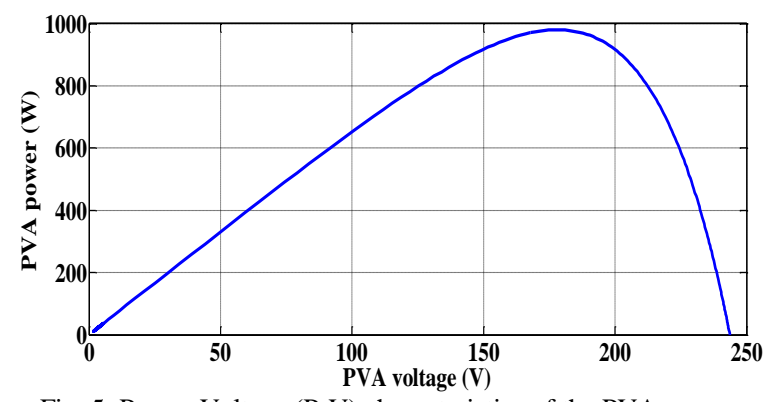

Fig. 5: Power-Voltage (P-V) characteristics of the PVA

\section{B. EFFECT OF TEMPERATURE AND SOLAR RADIATION ON PV CHARACTERISTICS}

The PV module is examined under constant irradiation, $S_{x}=1000 \quad \mathrm{~W} / \mathrm{m}^{2}$, and different temperatures, $\left(T_{x}=25,50\right.$ and $\left.75^{\circ} \mathrm{C}\right)$. The related graphs are shown in Figs. 6 and 7. From Fig. 6, it is clear that as the temperature, increases the maximum power generation slightly decreases. Similarly in Fig. 7, it is observed that as the temperature increases the PV module output voltage slightly drops. This also agrees with the results given in [1216].

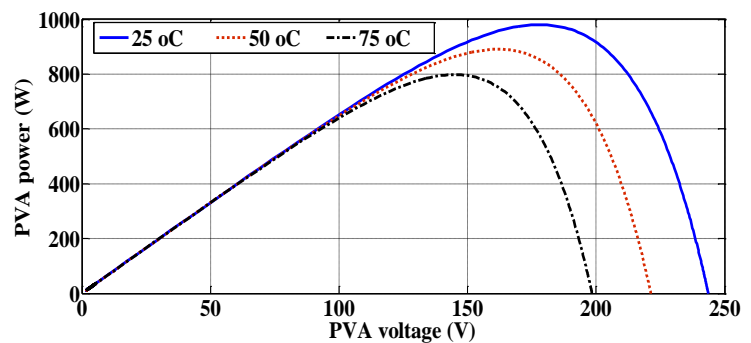

Fig. 6: P-V curves with different ambient temperatures.

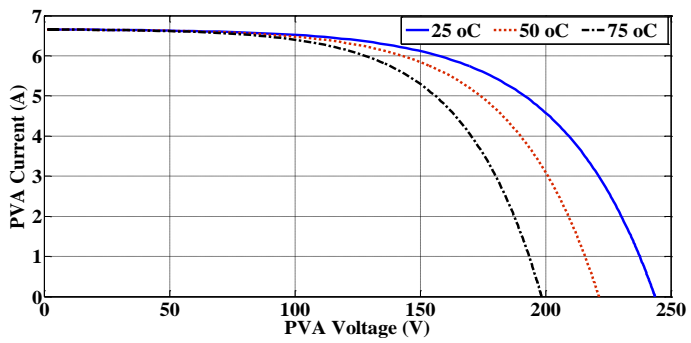

Fig. 7: I-V curves with different ambient temperatures.

For a constant temperature $\left(\mathrm{T}_{\mathrm{x}}=25{ }^{\circ} \mathrm{C}\right)$ and different solar radiations $\left(S_{c}\right.$ varies between 1000 to $3000 \mathrm{~W} / \mathrm{m}^{2}$ ), the related graphs are shown in Figs. 8 and 9. From Fig. 8, it can be easily realized that as the solar irradiation increases, the maximum power generation increases. Similarly, from Fig. 9, it is observed that as the solar irradiation increases, the PV module output current increases. These results agreed with the results presented in [12-16].

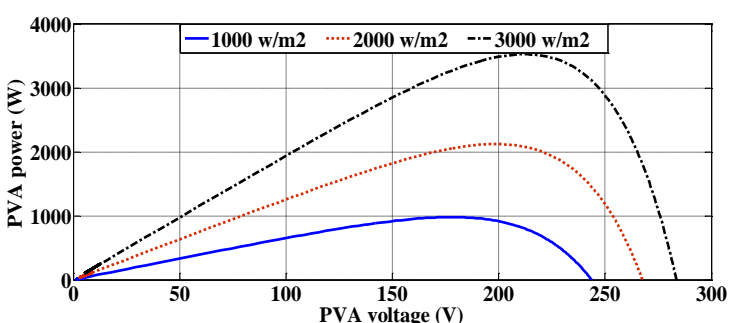

Fig. 8: P-V curves with different solar irradiations.

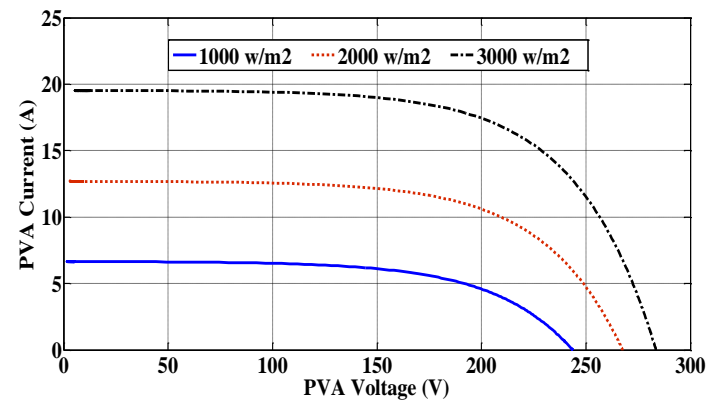

Fig.9: I-V curves with different solar irradiations.

\section{EFFECT OF DC LINK CAPACITANCE ON PV OPERATION WITH FLUCTUATED DC RESISTIVE LOAD}

The proposed PVA model is simulated as described in the schematic diagram given in Fig. 1. The PV array under the constant solar irradiation and ambient temperature with fluctuated dc resistive loads $(500 \mathrm{~W}, 300 \mathrm{~W}, 100 \mathrm{~W}$ and $200 \mathrm{~W}$ ) is connected in parallel. A dc link capacitor of $500 * 10^{-3} \mathrm{~F}$ is connected in parallel with the PV array. The diode $\mathrm{D}_{1}$ is connected in series with the PV Array to prevent the reverse current flow. The input filters contain a series R-L and parallel $\mathrm{C}$ elements to maintain a stable $\mathrm{dc}$ voltage. The average power of the fluctuated dc resistive load equals average PVA power at $T_{x}=25^{\circ} \mathrm{C}$ and $S_{x}=1000 \mathrm{~W} / \mathrm{m}^{2}$.

It is observed that the connected loads average power $\left(\mathrm{P}_{\text {load }}\right)$ is equal to the PVA average power $\left(\mathrm{P}_{\mathrm{PV}}\right)$ as shown Fig. 10. The maximum PVA power is around $1000 \mathrm{~W}$, while dc load power varies with \pm $10 \%$. The dc capacitor connected in parallel with PVA and $\mathrm{dc}$ load accommodates of the generation/load mismatch. However, as shown in Fig. 11, the generation power goes up and down following the loading variation trend since no dc link capacitor is connected. This phenomenon of instability in power as a result of being connected or not connected to the dc link capacitance is due to instability in the current flowing to the added loads as shown Fig.12 and 13. 


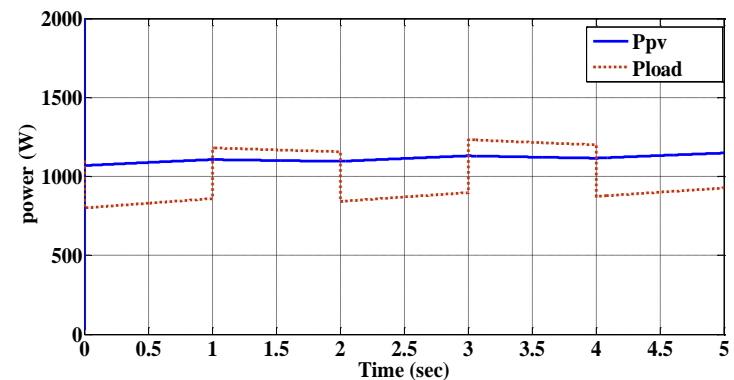

Fig. 10: Variation of the PVA and load powers with de link capacitor.

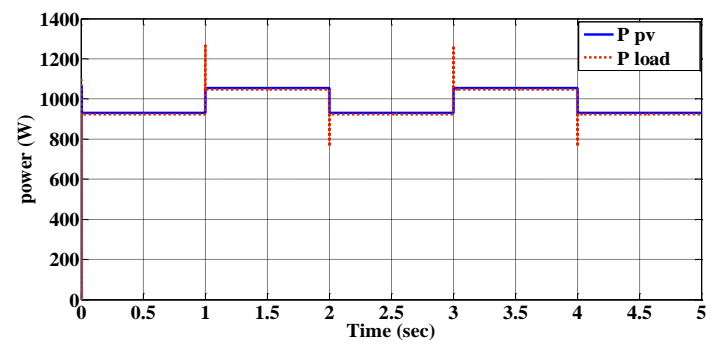

Fig. 11: Variation of the PVA and load powers without dc link capacitor.

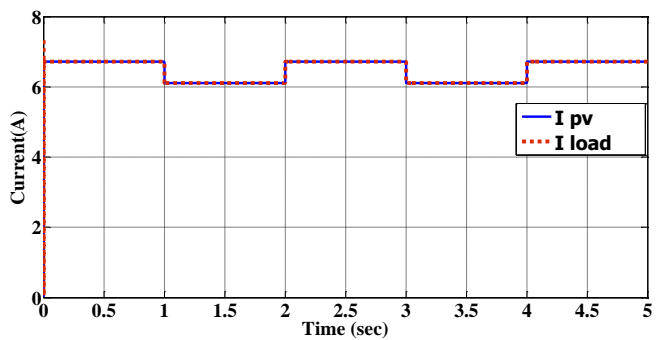

Fig. 12: Variation of the PVA and load current without dc link capacitor.

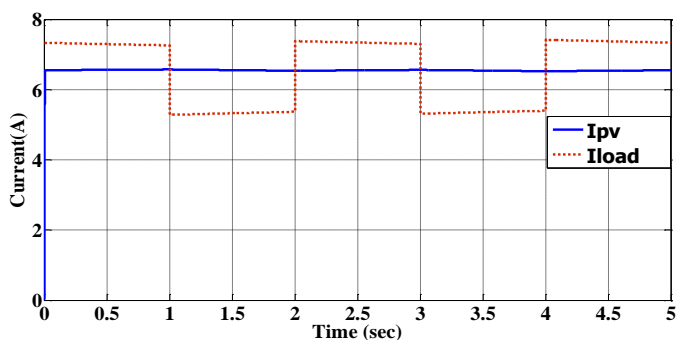

Fig. 13: Variation of the PVA and load current with dc link capacitor.

Fig. 14 shows the variation of the PVA and load voltages without capacitor banks. It is observed that, without capacitor banks, the PVA and load voltages are going up and down according to load decreasing and increasing. The dc capacitor connected in parallel with PVA and dc load accommodates of the generation/load mismatches, as shown in Fig. 15. PVA and load voltages are more stable. This reflects the importance of the dc capacitance as it acts as a buffer and minimizes the impact of load variations on the voltage profile.

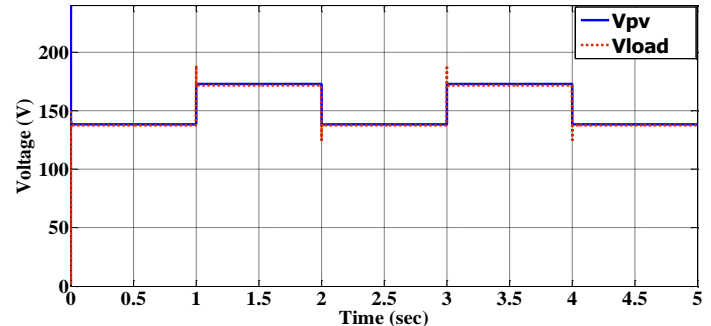

Fig. 14: Variation of the PVA and load voltage without dc link capacitor.

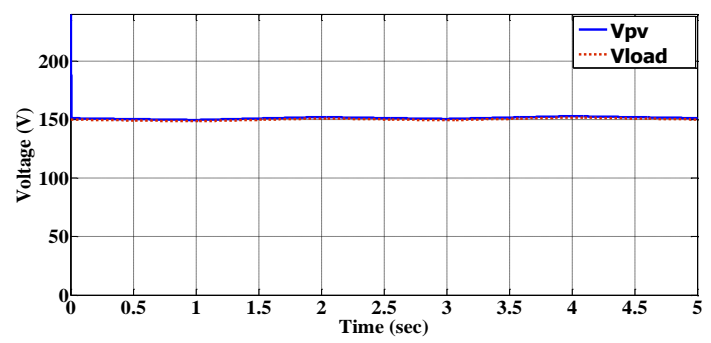

Fig. 15: Variation of the PVA and load voltage with dc link capacitor.

\section{SELECTION OF THE VALUE OF DC LINK CAPACITANCE FOR \\ FLUCTUATED DC RESISTIVE LOADS}

The variation of the PVA power, voltage and current with the values of capacitance are shown in Figs. 16 to 18 . It is observed that unstable in PVA characteristic at zero dc link capacitance. With increased value of dc link capacitance in parallel with loads, the PV array at constant solar irradiation and ambient temperature with fluctuated dc resistive load.

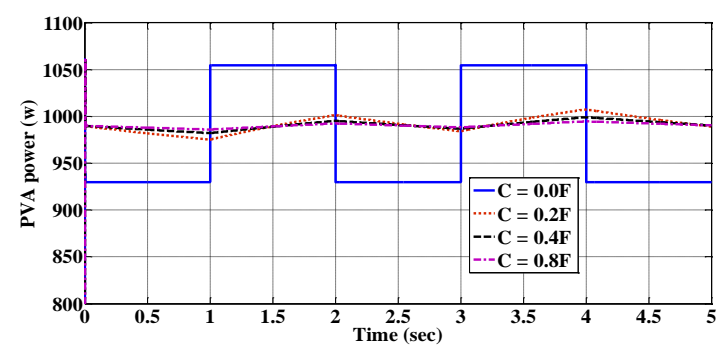

Fig. 16: Variation of the PVA power with different values of dc link capacitor.

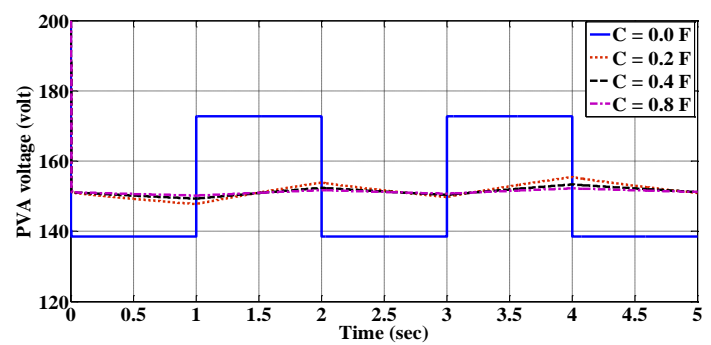

Fig. 17: Variation of the PVA voltage with different values of dc link capacitor. 


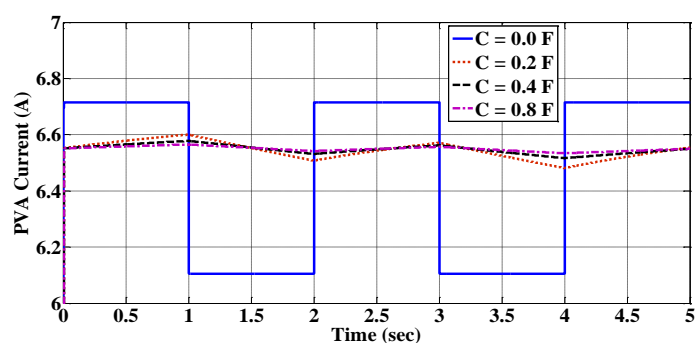

Fig. 18: Variation of the PVA current with different values of dc link capacitor.

Figs. 19 to 21 show variations of the load power, voltage and current with different values of dc capacitances. It is observed that an unstable operation occurs at zero dc link capacitance. However, with the increase of dc link capacitance, more stable system operation can be reached. The PV array is with fluctuated dc resistive load and subjected to constant solar irradiation and ambient temperature.

From the results, it can be seen that the value of dc link capacitance depends on PVA power and load variation percentage (dL\%) as depicted in Eqs. 8 and 9.

$\mathrm{C}_{\min }=0.0001 * \mathrm{P}_{\mathrm{pv}} * \mathrm{dL} \%$

$\mathrm{C}_{\max }=0.008 * \mathrm{P}_{\mathrm{pv}} * \mathrm{dL} \%$

Where:

$\mathrm{C}_{\min }$ : minimum value of $\mathrm{dc}$ link capacitance in Farad.

$\mathrm{C}_{\max }$ : maximum value of $\mathrm{dc}$ link capacitance in Farad.

$\mathrm{P}_{\mathrm{pv}}$ : PVA power in Watts.

$\mathrm{dL} \%$ : the percentage of dc resistive load variation.

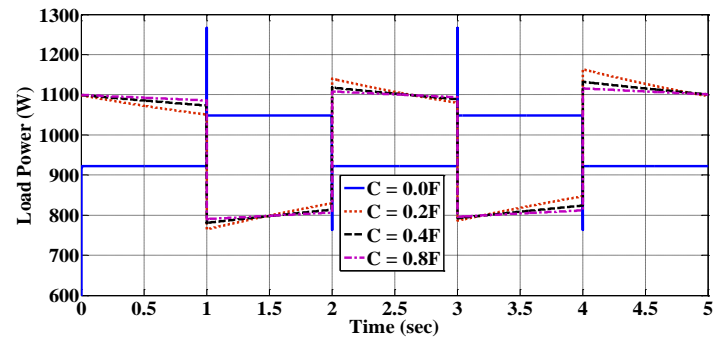

Fig. 19: Variation of the load power with different values of dc link capacitor.

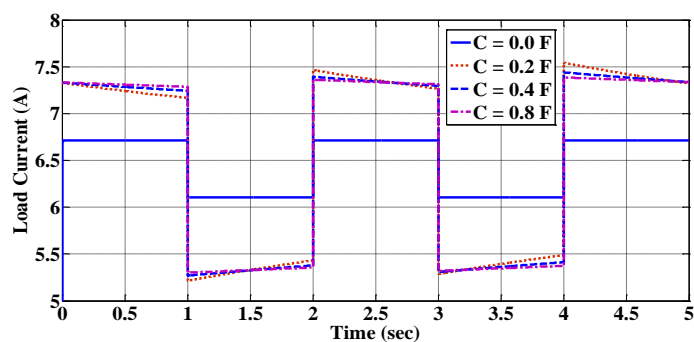

Fig. 20: Variation of the load current with different values of dc link capacitor.

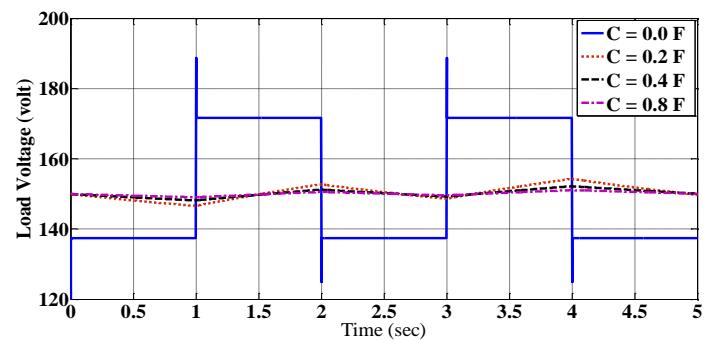

Fig. 21: Variation of the load voltage with different values of dc link capacitor.

\section{E. EFFECT OF DIFFERENT FLUCTUATED DC RESISTIVE LOAD ON PV \\ CHARACTERISTIC}

The variation of the PVA power, voltage and current with fluctuated dc resistive loads for $\pm 10 \%$ and $\pm 20 \%$ at constant dc link capacitor are shown in Figs. 22 to 24 . With different levels of fluctuations in the dc resistive loads, it is observed that PVA power, voltage, and current are affected as shown in Figs 22-24. Higher PVA average voltage and power injection are with the lowest load variation level $( \pm 10 \%)$. These results are given with constant dc link capacitor and constant solar irradiation/ambient temperature.

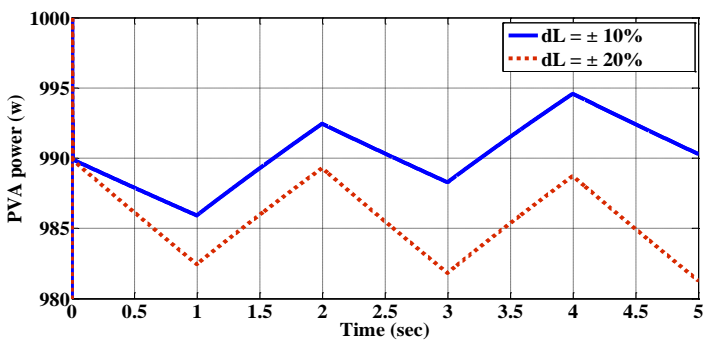

Fig. 22: Variation of the PVA power with fluctuated dc resistive load and constant dc link capacitor (0.8 Farads).

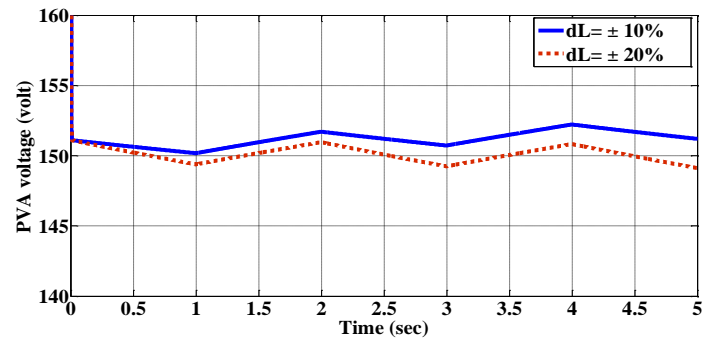

Fig. 23: Variation of the PVA voltage with fluctuated dc resistive load and constant de link capacitor (0.8 Farads).

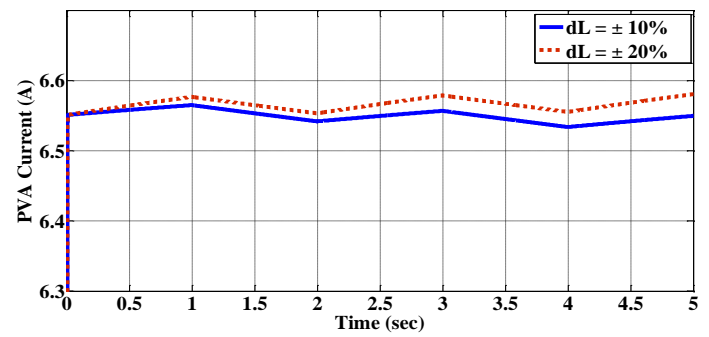

Fig. 24: Variation of the PVA current with fluctuated dc resistive load and constant de link capacitor (0.8 Farads). 


\section{F. EFFECT OF DC LINK CAPACITANCE ON PV OPERATION WITH FIXED DC \\ RESISTIVE LOAD AND VARIABLE SOLAR RADIATIONS AND AMBIENT TEMPERATURES}

Figs. 25 and 26 show the enforced variation of solar radiation and ambient temperature respectively. The PVA model is simulated as described in the schematic diagram given in Fig. 1. The PV array is subjected to variable solar radiation and ambient temperature and is connected to fixed dc resistive loads $(500 \mathrm{~W}$ and $300 \mathrm{~W})$. A dc link capacitor of $800 * 10^{-3} \mathrm{~F}$ is connected in parallel with the PV array. The diode $\mathrm{D}_{1}$ is connected in series with the PV Array to prevent the reverse current flow. The input filters contain a series R-L and parallel C elements to maintain a stable dc voltage. The average power of the fluctuated dc resistive load equals average PVA power at $T_{x}=25^{\circ} \mathrm{C}$ and $S_{x}=1000$ $\mathrm{W} / \mathrm{m}^{2}$.

Figs. 27 and 28 show respectively the PVA voltage and power variations caused by variable solar radiations and ambient temperatures with and without dc link capacitor. It is observed that the PVA voltage and power are smooth with the presence of the dc link capacitor. Similarly, with the presence of the dc capacitor connected the load current and power absorbed are smooth as shown Figs. 29 and 30.

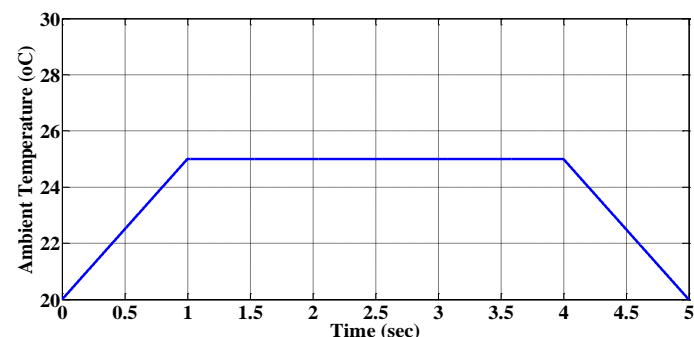

Fig. 25: Variation of ambient temperature.

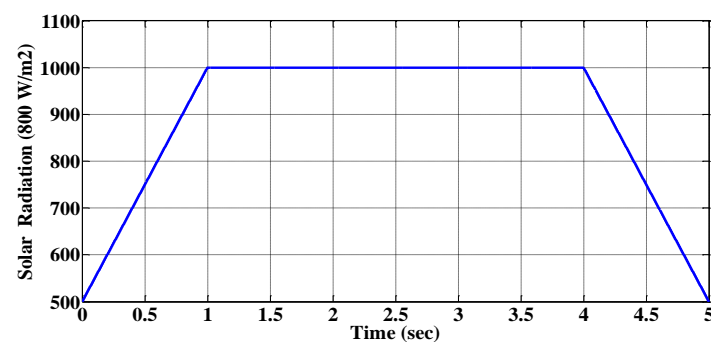

Fig. 26: Variation of solar radiation.

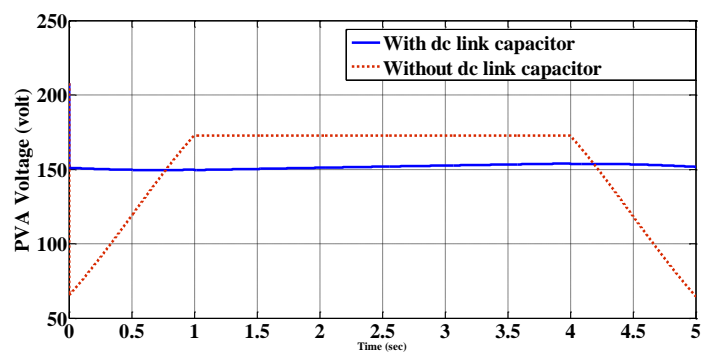

Fig. 27: Variation of the PVA voltage with and without dc link capacitor under variable solar radiation and ambient temperature.

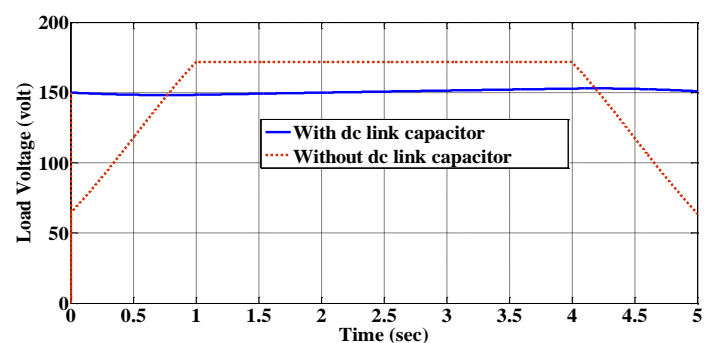

Fig. 28: Variation of the load voltage with and without de link capacitor under variable solar radiations and ambient temperatures.

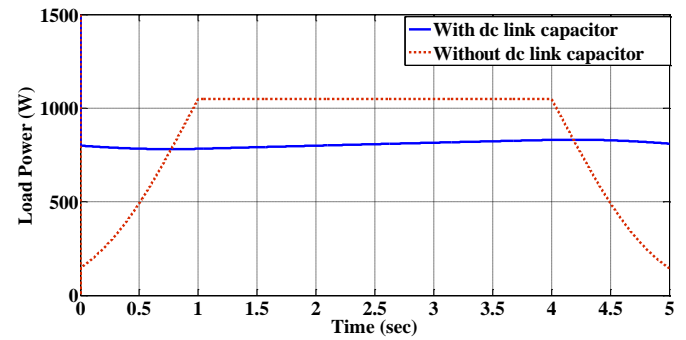

Fig. 29: Variation of the load power with and without dc link capacitor under the variation of solar radiation and ambient temperature.

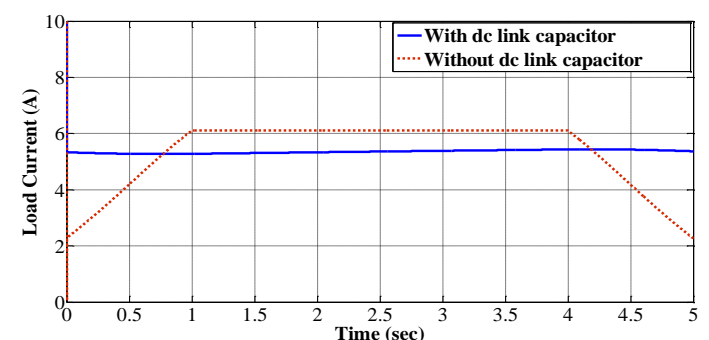

Fig. 30: Variation of the load current with and without dc link capacitor under the variation of solar radiation and ambient temperature.

\section{CONCLUSIONS}

This paper presents a MATLAB/SIMULINK based modeling and simulation scheme suitable for studying the $I-V$ and $P-V$ characteristics of a PV array under constant and variable solar irradiations and ambient temperatures. The PV array is connected with fluctuated dc resistive load. The input filters contain a series R-L and parallel C elements to maintain a stable dc voltage. The effect of the dc link capacitance on standalone photovoltaic system operation with fluctuated dc resistive load is the paper core. The dc capacitor connected in parallel with PVA and dc load accommodates the generation/load mismatch. As the value of dc link capacitance increases, better voltage profile can be realized. Different dc resistive loads with $\pm 10 \%$ and $\pm 20 \%$ variations are conducted to examine the impact of the dc link capacitance. From simulation results, it can be realized that the value of dc link capacitance depends on PVA power and the dc resistive variation. An empirical estimation has been deduced. 
This paper focuses also on addressing the effect of dc link capacitance on stand-alone PV system operation with a fixed dc resistive load subjected to variable solar radiations and ambient temperatures. The variation of the PVA and load voltage with and without dc link capacitor is conducted. A stable dc voltage and smooth load current is prevailed with the presence of the dc link capacitor.

\section{REFERENCES}

[1] I. H. Altas and A. M. Sharaf, "A photovoltaic array simulation model for Matlab-simulink GUI environment," IEEE International Conference on Clean Electrical Power, ICCEP, '07, pp. 341-345, Capri, Italy, 21-23 May 2007.

[2] S. B. Kjaer, J. K. Pedersen and F. Blaabjerg, "A review of single-phase grid-connected inverters for photovoltaic modules," IEEE Trans. Ind. Applications, vol. 41, no. 5, pp 1292-1308, Sep./Oct. 2005.

[3] A. M. Sharaf and L. Yang, "A novel maximum power tracking controller for a stand-alone photovoltaic dc motor drive," $18^{\text {th }}$ Annual Canadian Conference on Electrical and Computer Engineering (CCECE05), Saskatoon, Canada, pp. 450 - 453, May 2006.

[4] M. E. Ropp and S. Gonzalez, "Development of a MATLAB/Simulink model of a single-phase gridconnected photovoltaic system," IEEE Trans. Energy Convers, vol. 24, pp. 195-202, March 2009.

[5] Y. Mahmoud and H. H. Zeineldin, "A simple approach to modeling and simulation of photovoltaic modules," IEEE Trans. Sustainable Energy, vol. 3, no. 1, pp. 185 - 186, January 2012

[6] G. Walker, "Evaluating MPPT converter topologies using a MATLAB PV model," Journal of Electrical and Electronics Engineering, Australia, vol. 21, no. 1, pp. 49-55, 2001.

[7] J. A. Gow and C. D. Manning, "Development of a photovoltaic array model for use in power electronics simulation studies," IEE Proceedings on Electric Power Applications, vol. 146, no. 2, pp. 193-200, March 1999.
[8] M. Abdulkadir, A. S. Samosir, A. H. M. Yatim and S. T. Yusuf, "A new approach of modelling, simulation of MPPT for photovoltaic system in simulink model," ARPN Journal of Engineering and Applied Sciences, vol. 8, no. 7, pp. 488-494, July 2013.

[9] H. Patel and V. Agarwal, "MATLAB-based modeling to study the effects of partial shading on PV array characteristics," IEEE Trans. Energy Convers, vol. 23, no. 1, pp. 302-310, March 2008.

[10] A. Francees and A. Sharaf, "A novel filter compensation scheme for hybrid (photovoltaic - fuel cell) - dc utilization systems," International Journal of Advanced Renewable Energy Research, vol. 1, no. 6, pp. 283-291, 2012.

[11] R. Ayaz, I. Nakir, and M. Tanrioven, "An Improved Matlab-Simulink Model of PV Module considering Ambient Conditions," International Journal of Photoenergy, vol. 10, no. 6, 2014.

[12] A. A. Elbaset, H. Ali and M. Abd-ElSattar, "Novel seven-parameter model for photovoltaic modules," journal Elsevier, Solar Energy Materials and Solar Cells, vol. 130, pp. 442-455, November 2014.

[13] J. S. C. Mano Raj and A. E. Jeyakumar, "A novel maximum power point tracking technique for photovoltaic module based on power plane analysis of I-V characteristics," IEEE Trans. Industrial Electronics, vol. 61, no. 9, September 2014.

[14] L. Rachedi, C. Fetha, T. Bahi and H. Bouzeria, "Design of a fuzzy logic controller for PV applications," Conference International des Energies Renouvelables, vol. 2, no. 6, 2013.

[15] B. C. Babu, Sriharsha, A. Kumar and S. R. Samantaray, "Design and implementation of low power smart PV energy system for portable applications using synchronous buck converter," IEEE International Symposium on Electronic System Design, vol. 56, no. 7, Dec. 2011.

[16] M. O. Badawy, A. S. Yilmaz, Y. Sozer and I. Husain, "Parallel power processing topology for solar PV applications," IEEE Trans. Ind. Applications, vol. 50, no. 2, pp. 4137 - 4144, March/April 2014. 